\title{
THE NEED FOR FOREST MANAGEMENT: A CASE STUDY OF THE NILWALA GANGA WATERSHED
}

\author{
M.D.C. Abhayaratna \\ Department of Geography, University of Sri Jayewardenepura
}

\begin{abstract}
Data are presented on deforestation since the 1950s, much of it due to illegal cultivation, including tea planting on steep slopes without adequate soilconservation precautions. The effects of deforestation on the soil and hydrology are discussed. Proposed remedial measures are centred on a participatory approach, involving $N G O$ s and extension work.
\end{abstract}

\section{Introduction}

The Nilwala Ganga watershed lies in the southern part of the wet zone of Sri Lanka. bordering on the intermediate zone in the east (Fig. 1). Ninety-two percent of it is in Matara District. Five percent in the northwest and three percent in the east are in Galle and Hambantota Districts respectively. The Nilwala Ganga starts at an elevation of $1067 \mathrm{~m}$ at Panilkanda and traverses $72 \mathrm{~km}$ before discharging to the sea at Matara.

More than a quarter of the watershed was under forest in the mid-1950s. However, the forest cover has dwindled very rapidly because of the fast growth rate of the population in the recent past. This deforestation has had many undesirable consequences such as acute soil erosion, increased surface runoff and land degradation in the upper watershed, and severe floods in the lower parts. Any aggravation of these problems will not only cause untold hardship to many poor agricultural land users but will also endanger the sustainability of the present land use. Planned interventions, in the form of controls and remedial action, are urgently needed.

The present study discusses the past and present distribution of forests in the watershed, highlighting the dwindling nature of the resource and the reasons that can be adduced for the change. The effects of the reduction of forest cover and the need for management interventions by way of controls and participatory approaches are also discussed. Finally, the paper refers to some NGO interventions and presents implications for policy. 


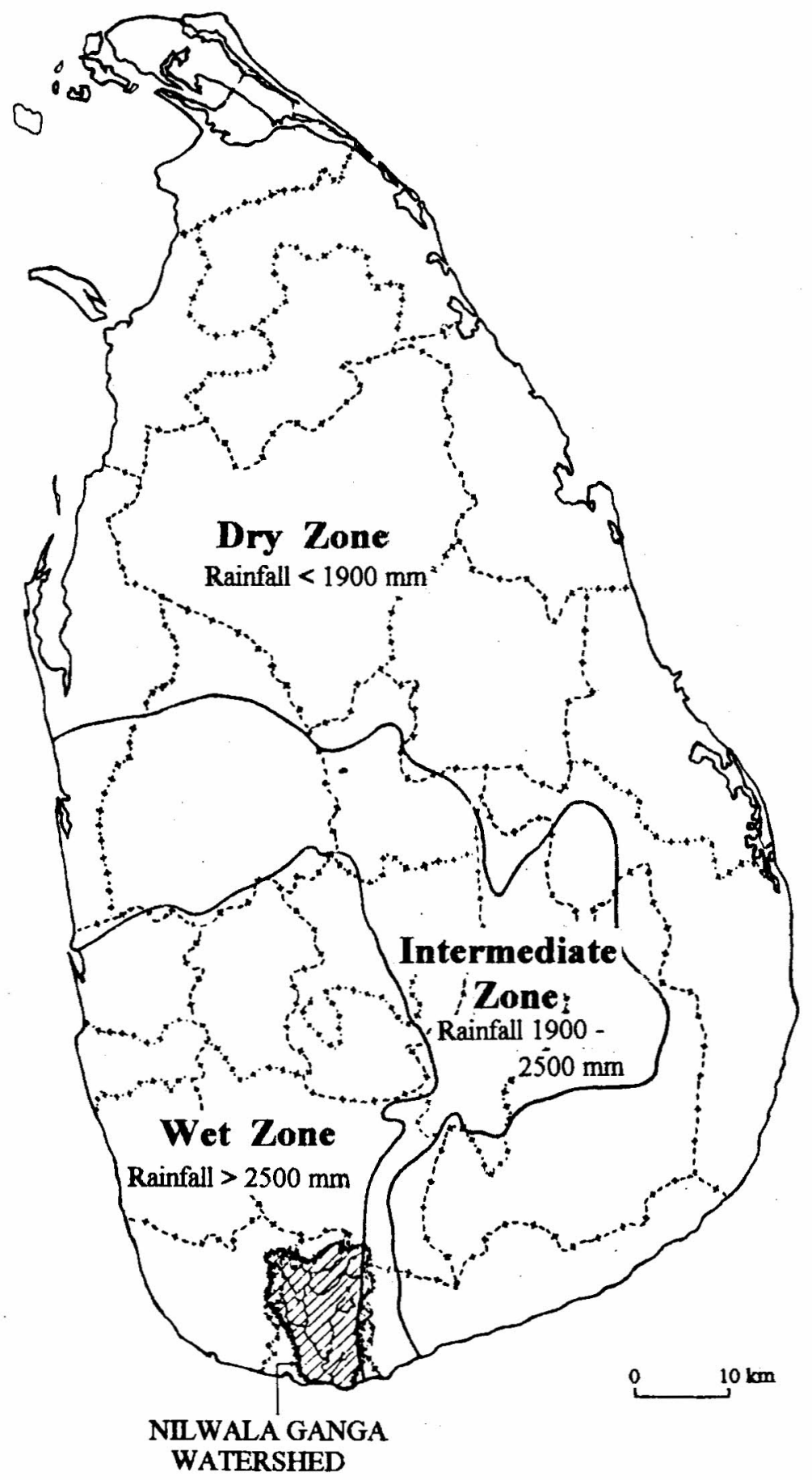

Figure1: Location map of Nilwala Ganga watersed 
The total area of the watershed is about $1073 \mathrm{~km}^{2}$ (LUPPD, 1995). It includes the subwatersheds of the Urubokke Ganga, Kotapola Ganga, Hulandawa Ganga, Siyambalagoda Ganga, Digili Oya and Kirama Ara. The highest parts are in the northeast. where the land rises above $150 \mathrm{~m}$. The river enters a vast flood plain south of Akuressa. including areas around Malimboda. Tihagoda, Sultanagoda and Hittetiya. In the southeastern part. where the seasonal concentration of rainfall poses problems for paddy cultivation, there are tanks such as Ellawala Wewa. Denagama Wewa and Kekunadura Wewa, that are used for irrigation.

The monthly temperatures show only slight variation within the year. Between 1990 and 1994 the lowest temperatures have been recorded in January and the highest in March-April (LUPPD, 1995). Although it varies with altitude, temperature is not a constraining factor either for plant growth or for human habitation.

There is a high rainfall distributed throughout the year, with a distinct bi-modal pattern at all stations, duc to the southwest monsoon in May and convectional activity reinforced by cyclones in November (Fig. 2). The annual amounts increase from less than $1750 \mathrm{~mm}$ in the southeastern part, in the intermediate zone, to about $4000 \mathrm{~mm}$ in the northwest: this gradual increase can be attributed to the topographic effect. The coefficient of variation is high in months with low rainfall and comparatively low in months with fairly high rainfall (Sirinanda, 1983). As Sirinanda has pointed out, rainfall in the wet zone falls within a range that can cause floods in the low-lying areas.

Rcd-yellow podzolic soils, which are associated with dissected, hilly and rolling terrain, predominate in the upper watershed. Alluvial soils are confined to the river valleys of the middle and lower parts of the watershed, while bog and semi-bog soils are found in the poorly drained lower reaches of the flood plain. Regosols on beach sands occur in a small patch bordering the sea coast.

\section{Past and present distribution of forests}

Calculations based on the Hunting Survey Corporation maps of land use and forest cover indicate that in the mid-1950) the total area under forests in the Nilwala Ganga watershed was about 27,360 ha These forests were largely within the wet zone. According to their yield potential they were classified into high-yield, medium-yield, low-yield and non-productive catcgories.

A classification based on forest types shows that lowland rain forest is the most dominant. It is associated with high temperatures of about $27^{\circ} \mathrm{C}$, a well distributed annual rainfall of more than $2500 \mathrm{~mm}$, and a relative humidity from 75 to $90 \%$. Species such as hora, dorana, kirihambiliya and kekuna constitute the highest canopy, and na, atamba, milla, hadawaka and domba are important in the second canopy. Lower strata are represented by kitul, godapara, diyapara, bata and ma wewal. There are a few patches of moist monsoon and dry monsoon forest in the eastern and southeastern sector 


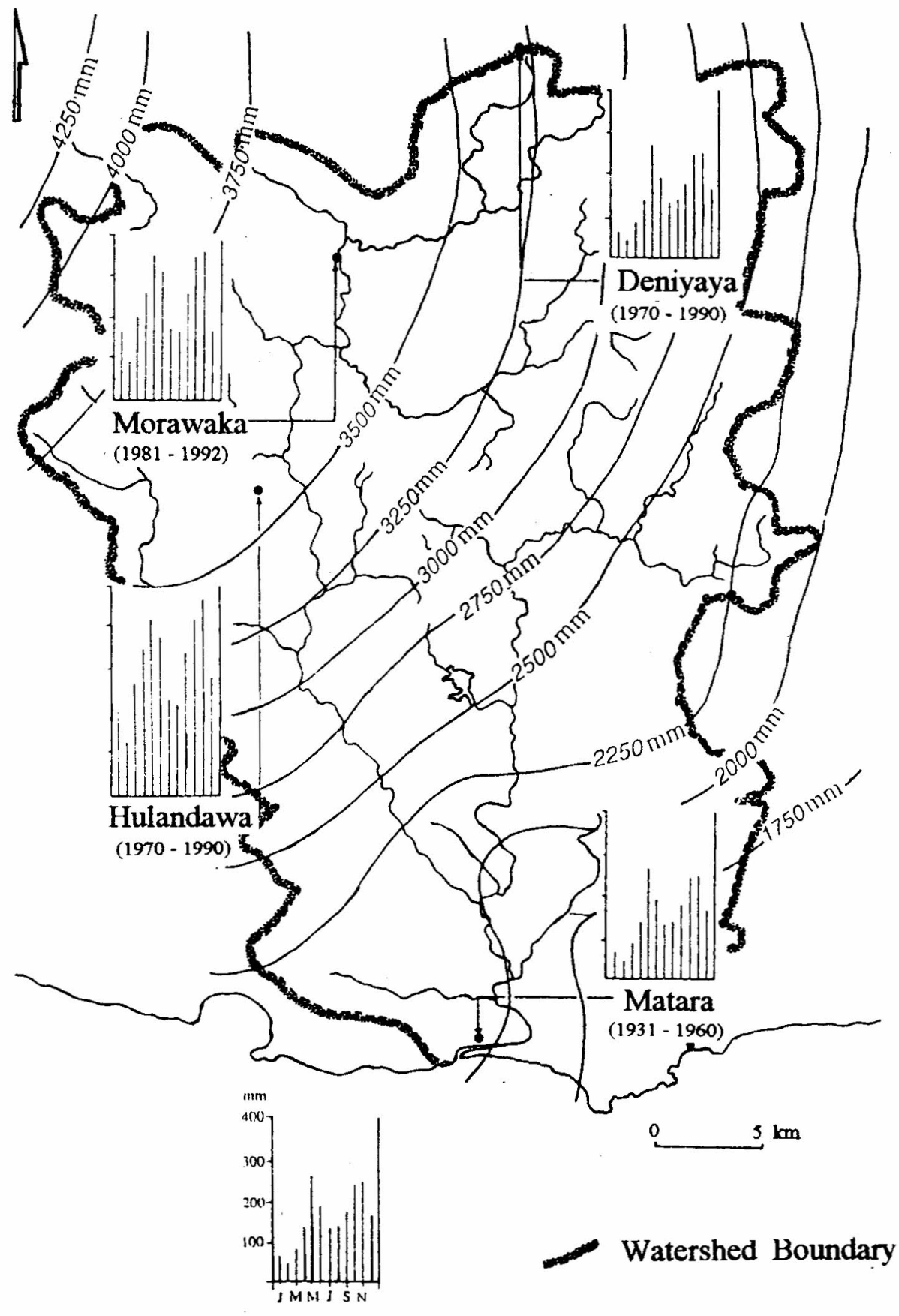

Mean Annual Rainfall in Milimeters

Figure 2: Distribution of mean annual rainfall 
of the watershed. These types are associated with the rainfall ranging from 1900 to $2500 \mathrm{~mm}$. and high temperatures of about 27 to $30^{\circ} \mathrm{C}$, that are characteristic of the intermediate zone. The seasonal nature of the rainfall exerts a strong influence on both these forest types. Growth is rapid during only a few months of the ycar (OctoberJanuary) when most of the rainfall is received. In comparatively wetter parts of the intermediate zone, trees such as lunumidella and pihimbiya are more frequent.

Dry monsoon forests are restricted to one or two patches in the extreme southeast corner of the watershed, bordering the Hambantota District, where the rainfall is comparatively low. These forests are characterized by the absence of a continuous canopy. Both cvergreen and deciduous trees are present. The density of the stands. as well as the number of species, is less than that of the rain forests. The tallest trees are about $20 \mathrm{~m}$. Among the main species are satinwood, milla, halmilla, wood-apple, and hulanhik.

The forests come under two major pieces of legislation: the Forest Ordinance, No. 16 of 1907, as amended by Act No. 13 of 1966 and subsequent amendments: and the National Heritage and Wilderness Areas Act. No. 3 of 1988. Most of them are gazetted as Forest Reserves (FRs) under the Forest Ordinance. Table I lists the FRs in the watershed with their areas and the dates they were gazetted. All FRs except Mulatiyana were gazetted in 1940 or earlier. In Diyadawa, Mulatiyana. Oliyagankele, Rammalkanda and Kanumuldeniya (which belong to both Matara and Hambantota Districts) parts of each FR are designated as Man and Biosphere (M\&B) Reserves under the National Heritage and Wilderness Areas Act of 1988.

Table 1 : Forest Reserves of the Nilwala Ganga watershed

\begin{tabular}{lccl}
\hline \multicolumn{1}{c}{ Forest reserve } & Date gazetted & Gazetted area (ha) & Present area (ha) \\
\hline Badullakele & 11.10 .40 & 182.3 & 147.7 \\
Dandeniya-Aparekka & 7.1 .21 & 560.0 & 348.3 \\
Dediyagala (G \& M)* & 6.9 .40 & 3789.9 & 3789.9 \\
Diyadawa & 21.8 .36 & 2578.2 & 2447.7 \\
Kalugalkanda & 10.11 .93 & 62.5 & 62.5 \\
Kanumuldeniya (H \& M)** & 13.9 .40 & 678.7 & 678.7 \\
Kekanadura & 15.11 .35 & 401.7 & 379.9 \\
Kirinda-Mahayayakele & 19.7 .40 & 374.1 & 252.7 \\
Masmullekele & 21.7 .39 & 805.4 & 618.0 \\
Mulatiyana & 25.8 .44 & 3277.5 & 314.9 \\
Oliyagankele & 8.9 .39 & 888.6 & 886.0 \\
Panilkanda & 18.3 .28 & 588.1 & 588.1 \\
Rammalkanda & 21.5 .26 & 1698.1 & 1406.7 \\
Viharekele & 26.4 .35 & 825.1 & 625.1 \\
Welihena & 15.11 .35 & 333.1 & 296.8 \\
Wellama & 23.12 .32 & 85.4 & 85.4 \\
\hline
\end{tabular}

* Belongs to both Galle and Matara Districts

**Belongs to both Hambantota and Matara Districts

Source: Forestry Sector Master Plan (1995) 


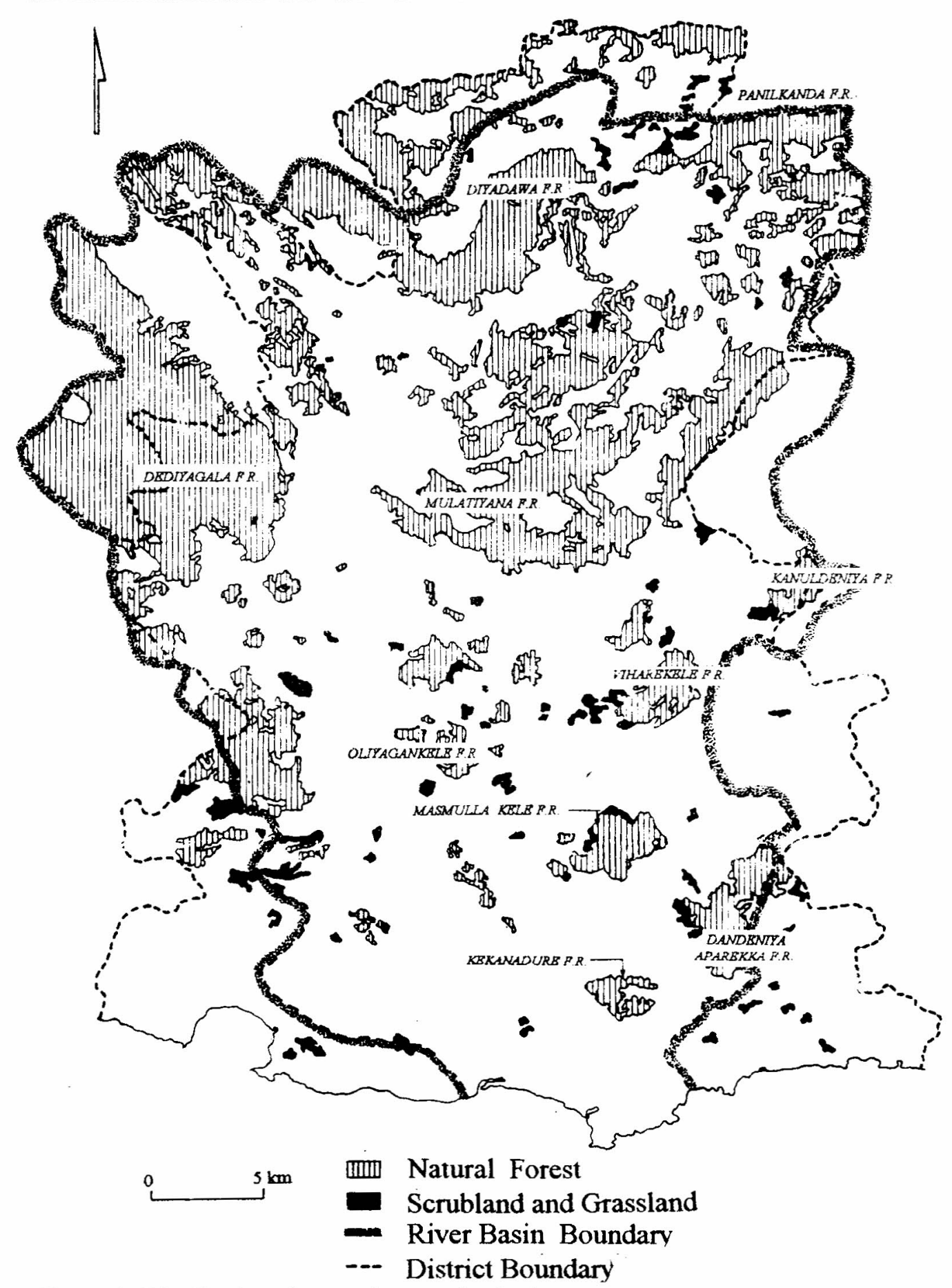

Figure 3: Distribution of natural vegetation in the area 
The forest area in the watershed dwindled from 27,360 ha in the mid-1950s to 16,848 by the mid-1980s. a decline of $38 \%$ in about three decades. It dwindled again to 15,887 ha by 1995 , a further reduction of $6 \%$. The distribution of forests in the FRs is shown in Fig. 3. Note that the statistics for Matara District in Table 2 are slightly higher, as they have not been updated.

Table 2 shows the distribution of forests falling within the watershed in Matara District, by Divisional Secretaries' (DS) Divisions. There are none in the Malimboda (Weligam Korale South) and Dikwella (Wellaboda Pattu East) Divisions. It should also be noted that there are no dense forests in the Hakmana and Weligama Divisions. By the mid80) $.39 .5 \%$ of the forests were in the Kotapola and 31.4 in the Akuressa Divisions. The inclusion of a part of the Sinharaja Forest Reserve and the forested Rakwana Range in Kotapola, and the presence of Beraliya, Dediyagala, Welihinda, Oliyagankele and Kalugalkanda FRs in Akuressa account for the heavy concentration of forests in the two Divisions. Thihagoda and Hakmana D.S. Divisions together have less than one percent of the forest area of the Matara District.

Table 2 : Distribution of forests in the Nilwala Ganga watershed by DS Division (mid-1980s)

\begin{tabular}{lcc}
\hline \multicolumn{1}{c}{ DS Division } & Area under forests (ha) & Percentage \\
\hline Akuressa & 5,072 & 31.4 \\
Dikivella &..- &..- \\
Hakmana & 20 & 0.1 \\
Kamburnpitiya & 770 & 4.9 \\
Kotapola & 6,375 & 39.5 \\
Malimboda & -- &.-- \\
Mutara \& Devinuwara & 520 & 3.2 \\
Mulatiyana & 1,230 & 7.6 \\
P'asgoda & 1,909 & 11.8 \\
Thihagoda & 120 & 0.7 \\
Weligama & 126 & 0.8 \\
Matara District & $\mathbf{1 6 , 1 6 2}$ & $\mathbf{1 0 0 . 0}$ \\
\hline
\end{tabular}

Source: CRS Map Matara 1985, Survey Department

\section{Reasons for the reduction of forest cover}

The reasons for the destruction of the forest resources derive mainly from the increase of population. In the 1971 census Matara District had a total population of 520,334, a density of 406 per $\mathrm{km}^{2}$. (Table 3). The figure increased to 643,786 at the 1981 census and to 754,045 by 1994 , corresponding to densities 502 and 588 per $\mathrm{km}^{2}$. However, the densily varied among different DS Divisions. In 1971 Pasgoda had the least (251 per $\mathrm{km}^{2}$ ) and Welleboda Pattu and Four Gravets the greatest (835). In 1981, Kotapola and Pitabaddera had the least (267) and Weligama the greatest (1796). Matara (Four Gravets) and Dikwella also had densities of more than 1000 per $\mathrm{km}^{2}$. In 1994 Akuressa had the least. with 282 per $\mathrm{km}^{2}$; this is because of the vast area covered by this division 
and the comparatively large area under forests. Weligama, Four Gravets and Dikwella again recorded very high densities in 1994.

Increasing population naturally resulted in diminishing areas of land per person. They were as low as 0.6 ha in the southern divisions such as Matara, Devinuwara and Dikwella. Even in the upper part of the watershed in the Pasgoda and Kotapola Divisions the area declined from 0.4 ha per person in 1971 to 0.3 in 1994. The resulting heavy pressure of population on land led to a significant increase in landlessness. Although there is no statistical information on migration between the DS Divisions of Matara District, field observations indicate that the landless people (and land-grabbers) from the southern divisions have migrated to the northern divisions of the watershed to encroach upon state land, particularly to pursue tea cultivation.

Table 3 : Population distribution in Matara District, by DS Division (1971-1994)

\begin{tabular}{|c|c|c|c|c|c|c|}
\hline & \multicolumn{2}{|c|}{1971} & \multicolumn{2}{|c|}{1981} & \multicolumn{2}{|c|}{1994} \\
\hline & $\begin{array}{l}\text { Popu- } \\
\text { lation }\end{array}$ & $\begin{array}{l}\text { Density } \\
\text { per km² }\end{array}$ & $\begin{array}{l}\text { Popu- } \\
\text { lation }\end{array}$ & $\begin{array}{l}\text { Density } \\
\text { per km² }\end{array}$ & $\begin{array}{l}\text { Popu- } \\
\text { lation }\end{array}$ & $\begin{array}{l}\text { Density } \\
\text { per km² }\end{array}$ \\
\hline Akuressa & 70,948 & 281 & 72,909 & 289 & 71,054 & 282 \\
\hline Dikwella & & & 48,210 & 1079 & 49,919 & 1118 \\
\hline Hakmana & 68,422 & 410 & 31.752 & 608 & 33,186 & 635 \\
\hline Kamburupitiya & & & 42.169 & 528 & 58,626 & 735 \\
\hline Kotapola & 73.520 & 228 & 86,088 & 267 & 106,219 & 330 \\
\hline Malimboda & & & 26,882 & 405 & 30,068 & 454 \\
\hline Matara \& & & & & & & \\
\hline Devinuwara & 119,300 & 835 & 125,995 & 1293 & 160,725 & 1636 \\
\hline Mulatiyana & & & 41,688 & 363 & 44.308 & 386 \\
\hline Pasgoda & 36.965 & 251 & 45.502 & 310 & 55.231 & 376 \\
\hline Thihagoda & 66,725 & 503 & 28.829 & 546 & 31,869 & 604 \\
\hline Weligama & 84,458 & 713 & 93.762 & 1796 & 112,840 & 2162 \\
\hline District total & 520,334 & 406 & 643,786 & 502 & 754,045 & 588 \\
\hline
\end{tabular}

Source: Census of Population 1971 and 1981. and Demographic Survey 1994.

Department of Census and Statistics.

Settlement in the watershed and the expansion of tea cultivation have taken place mainly at the cost of forest land. In the first instance encroachments were into the small patches of village forest formerly administered by the Government Agents, and now by the Divisional Secretaries. With further increase of population there was immense pressure on the Proposed Forest Reserves that come under the Forest Department. Then those FRs that did not have marked boundaries were encroached upon. Table 1 clearly shows that the areas originally gazetted under the Forest Ordinance are no longer to be found in many of the FRs in the watershed. This is an indication that the forests have dwindled to accommodate settlements, urban development, cultivation, and other activities such as the construction of roads and irrigation schemes.

Large-scale felling of valuable timber for construction purposes and for the furniture industry has also contributed to the depletion of the forest resources. It has been revealed that in the upper parts of the watershed, some sub-watersheds such as 
Aninkanda, Millawa Ela and Horagala are completely degraded because of illegal forest clearance and the exposure of the land to acute soil erosion.

Although the exact amounts cannot be calculated, the extraction of wood to satisfy domestic fuel necds has also imposed a considerable strain on the forest resources. Despite the attempts made at reforestation, only 2625 ha were under forest plantations at the end of 1994 (Administration Report of the Conservator of Forests, 1994). It is clear that the area reforested is not at all adequate to compensate for the destruction of forests in this part of the country.

\section{Effects of forest reduction}

Forest reduction has many adverse effects. Clearance and utilization of the higher slopes for culti-vation, without recourse to proper land management practices, have resulted in excessive soil erosion and increased runoff (discharge). Abernarthy (1976) has put the average annual increase in the ratio of runoff to rainfall for the Nilwala Ganga at $2.17 \%$. This excessive increase, perhaps the highest for all the river basins studied in Sri Lanka, can be largely attributed to the deforestation of the higher slopes.

Increased surface runoff has resulted in excessive soil erosion leading to the degradation of land. Many instances from the upper Nilwala watershed can be cited as examples. A study conducted by the Land Use Policy Planning Division (LUPPD) of the Ministry of Lands (1995) has highlighted the adverse impacts of deforestation in a number of sites in the upper Nilwala watershed. In the sub-watershed of the Millawa Ela, which drains to the main river near Morawaka, cultivation of steep slopes has expanded right into the Diyadawa FR. It is noted that the smaller streams of this sub-watershed dry up during many months of the year. Landslides have been observed at Tenipita in the Kotapola DS Division, where deforestation and land degradation are aggravated by poor land-use practices. At Aninkanda, in the Kotapola and Pasgoda DS Divisions, the land has been largely cleared for tea. Small holders' tea land, as well as that of the tea estates, is on steep slopes and soil erosion is an acute problem; land degradation and drying-up of streams are also commonplace. Paragaha Ela, in the Aninkanda sub-watershed, is completely dry, and even the stream-bed itself has been used by cultivators (IIMI/SLFO, 1994). In the Horagala sub-watershed, which starts in the forest area of Ketakanda, steep land is used for tea cultivation. This area is completely deforested and encroached upon. Here also the drying up of streams, soil erosion, and land degradation are serious problems.

The expansion of cultivation into reservations can be observed throughout the watershed. In the upper parts, encroachment for tea cultivation commonly extends into statc lands on the high slopes, and also into stream and river reservations. It is observed that these areas are very poorly managed, as they are held by tea small holders who cannot enjoy state support because they have no legal entitlement to the land. Land management is poor, however, even on the estates. Some estates in the upper watershed have been abandoned because of low yields. 
As a result of deforestation, infiltration has been reduced and surface nunoff increased. The local water-table has been lowered, there has been unprecedented drying-up of water courses, drying of the top soil layers as soon as the rain stops, and a shortage of water both for cultivation and for domestic requirements.

\section{The need for intervention}

There is no doubt that intervention is vitally needed to check the destruction of forests and to prevent undesirable land use. As has been emphasized in the Forestry Sector Master Plan (1995) and in many other studies, the very extensive clearance of forests is a threat to the biodiversity of the rain forests, which are noted for their high percentage endemicity. It is common knowledge that the self-interested people responsible for the destruction will not stop of their own free will. Moreover, legislation in itself will not be a deterrent in the absence of efficient institutions for its implementation. On the other hand. past experience in Sri Lanka and elsewhere has pointed to the fact that the involvement of local people and the adoption of participatory management procedures vield better results than those obtained solely by law enforcement.

People's participation can be promoted only by the intervention either of the state or of NGOs, or by the joint efforts of both. It may be in the form of awareness programmes. catalytic action, incentives, formation of grass-roots institutions, or by a combination of such activities. The ultimate objective of these interventions is to mobilize people for participatory action with a view to ensuring sustainable use of forests and to enhancing the resource by reforestation. A forestry programme should fit into an overall land-use plan. In areas where land degradation has already taken place, a concerted effort should be made at rehabilitation. These objectives can be achieved only through thoughtfully planned interventions.

\section{The kind of interventions needed}

Early government interventions in forestry were mainly in the field of law enforcement. However, because of the inadequacy of field staff and single-handed coverage of vast areas by field officers, the difficulties of travelling in remote areas, and the delays associated with legal procedures, the Forest Department was greatly impeded in maintaining effective control. The large number of forest offences committed each year indicates that prohibition alone cannot stop the illegal clearance of forests.

Changes in policy and the adoption of participatory approaches have been evident in forest management in recent years. Reforestation programmes are envisaged with mass support from the nural people. The encouragement of NGOs to enter the field of forestry and the formation of grass-root institutions to activate an effective response to extension work are commendable effects of the new policies. 
During recent years many progressive steps have been taken in the upper watershed by the Shared Control of Natural Resources (SCOR) Project. In particular, an awareness programme and an effective participatory approach have made the people understand the devastation already done and the imminent threat to the sustainability of the existing land-use system. The project is sponsored by the Sri Lanka Field Operations section of the International Irrigation Management Institute (SLFO/IIMI) Although these interventions are not cqually successful everywhere, there are some success stories. The establishment of the Dotalugala Heritage is a case in point. In this case the people of the village bordering the forest have organized themselves into a local NGO to protect the forest area with a view to avoiding undesirable effects on land use on the lower slopes. They have also started a reforestation programme. SLFO/IIMI intends to extend this type of intervention into other areas of the upper watershed which are adversely affected by deforestestation.

\section{Implications for policy}

It is clear that continued deforestation in the upper reaches of the Nilwala Ganga watcrshed has caused tremendous damage to the land resource and has already threatened the sustainability of the existing land uses. Strategies calling for mass participation of local communities and the mobilization of political support should therefore be evolved, in order to check further clearance of forests, particularly in the sensitive arcas of the upper parts of the watershed. There are many programmes already launched in this direction. They should be further strengthened at the grass-roots level with a view to maximising peoples' participation.

Stcps to arrest further deforcstation will not by themselves yield the desired results. It is vital to rehabilitate the land that has already been degraded in the upper watershed; this involves both state and private land. New policies should be evolved to grant utilization rights in the reforested areas to the members of the local communities, who will be taking part in growing the trees. Private land owners should be exposed to awareness programmes by an extension scrvice, and encouraged by incentive schemes to reforest degraded land and to adopt strict conservation methods in cultivated parts of the upper slopes.

Concessions made to tea smallholders should be subject to strict controls, and conditions should be imposed whenever sensitive areas are used for cultivation. With a view to discouraging tea cultivation on encroached land, the issue of permits to utilize state land for tea should be stopped. and deeds should not be given to hold state land that is already occupied, unless it is converted to forestry uses.

\section{References}

Abernathy, C.L. (1976). As quoted in the First Interim Report of the Land Commission, 1985. Government Publications Beuran, Colombo.

Department of Census and Statistics $(1971,1981)$. Census of population and housing, Colombo. 
Department of Census and Statistics (1994). Demographic survey, Colombo.

Forest Department (1994). Administration Report of the Conservator of Forests, Forest Department Battaramulla. .

IIML/SLFO (1994). Dotalugala Forest Reserve, its status and intervention. SCOR Monitor 1 (2\&3).

LUPPD (1995). Nilwala Ganga watershed: present status and proposed interventions under the Shared Control of Natural Resources (SCOR) Project. Consultancy report prepared for IIMI/SLFO (Unpublished).

Ministry of Agriculture, Lands and Forestry (1995). Sri Lanka Forestry Sector Master Plan. Forestry Planning Unit, Battaramulla.

Sirinanda, K.U. (1983). Rainfall variability patterns and agricultural production in Siri Lanka. In Climate, water and agriculture in Sri Lanka. M.M.Yoshino et al. (Eds.) University of Tsukuba, Japan. 